\title{
Spory o patriarchat symbolem zakończenia epoki synodalnej w dziejach Rosyjskiej Cerkwi Prawosławnej początków XX wieku
}

\author{
Kamila Pawełczyk-Dura \\ Archiwum Państwowe w Łodzi \\ Polska \\ pawelczyk.kamila@wp.pl
}

\begin{abstract}
Kamila Pawełczyk-Dura, Discussions of patriarchy the symbol of the end of the synodal period in the history of the Russian Orthodox Church of beginnings of the 20th century, Elpis, 19 2017: 43-50.
\end{abstract}

\begin{abstract}
The abandonment of traditions of patriarchy took place in Russia on beginnings of the 17th century. Decision of the tsar Peter I to appoint the collegial The Most Holy Governing Synod headed by Ober-Procurator became an object of disputes between supporters and opponents of the patriarchy. Discussions on the role and the place of the patriarch in the structure of the Russian Church were conducted during session of a Preconciliar Commission (1906-107) and The All Russian Sobor (1917-1918), restoring the dignity of the first bishop and ending polemics taken in this subject.

This paper is an attempt to approximate opposing positions. Through analysis of speeches of active participants of these assemblies was shown the diversity of evoked arguments of historical and canonical and contemporary needs of community.

Streszczenie: Odejście od patriarchatu nastąpiło w Rosji na początkach XVII wieku. Decyzja cara Piotra I o powołaniu kolegialnego Świątobliwego Synodu Rządzącego na czele z oberprokuratorem stała się przedmiotem sporów między zwolennikami i przeciwnikami patriarchatu. Dyskusje o roli i miejscu patriarchy w strukturze rosyjskiego zarządu cerkiewnego wybrzmiały najpełniej podczas posiedzeń Komisji Przedsoborowej (1906-107) i Soboru Lokalnego (1917-1918), przywracającego godność pierwszego biskupa i stanowiącego symboliczne zakończenie polemik podejmowanych w tym temacie.

Niniejszy artykuł stanowi próbę przybliżenia przeciwstawnych stanowisk. Poprzez analizę wystąpień aktywnych uczestników tych zgromadzeń pokazano różnorodność przywoływanych argumentów historycznych i kanonicznych oraz współczesnych potrzeb wspólnoty.
\end{abstract}

Keywords: Russian Orthodox Church, patriarchy, a Preconciliar Commission 1906-107, The All Russian Sobor 1917-1918, Tikhon (Belavin)

Slowa kluczowe: Rosyjska Cerkiew Prawosławna, patriarchat, Komisja Przedsoborowa 1906-1907, Sobór Lokalny 1917-1918, Tichon (Biełławin)

Epokę synodalną w dziejach Rosyjskiej Cerkwi Prawosławnej otworzył ukaz z 25 stycznia 1721 roku. Manifestem o Kolegium Duchownym car Piotr I zniósł instytucję patriarchatu i godność pierwszego hierarchy, powołując w ich miejsce organ kolegialnego zarządu Kościołem - Świątobliwy Synod Rządzący ${ }^{1}$ i carskiego urzędnika w randze oberprokuratora. Idea funkcjonowania synodalnego systemu piotrowego już w XVIII wieku budziła kontrowersje. Odwołując się do tradycji Kościołów Wschodu, pielęgnującej hierarchiczne zwierzchnictwo patriarchy, wykazywano niekanoniczność decyzji cara, zerwanie z tra-

\footnotetext{
Podczas obrad Soboru Lokalnego, podjęto prace nad reformą tytulatur wewnątrzcerkiewnych. Wraz z powrotem do instytucji patriarchatu w Rosyjskiej Cerkwi Prawosławnej tytułem ,świątobliwego" obdarzono nowego patriarche (Światobliwy Patriarcha Moskiewski i Wszechrosji). To samo miano przysługiwało od 1721 roku Synodowi (Światobliwy Synod Rzadzacy). Na mocy postanowienia soborowego z 31 stycznia 1918 roku przyjetto zmiany w oficjalnym nazewnictwie. Przymiotnik „świątobliwy” został zachowany przy tytulaturze patriarchy. Świątobliwy Synod Rządzacy przemianowano na Święty Synod. Nazwa ta będzie stosowana w niniejszej pracy na określenie zgromadzenia funkcjonującego od 1917 roku. Zob.: М. А. Бабкин, Священство и Царство. Россия начало XX века - 1918 г. Исследования и материаль, Москва 2011, с. 495-496.
}

dycją Kościołów Wschodu, a nade wszystko na brzemienność likwidacji rosyjskiego tronu patriarszego. Pomimo oporu części świeckich i duchownych członków wspólnoty epoka synodalna utrzymała się blisko dwieście lat, a wyraźne symptomy jej zakończenia ujawniły się w rosyjskim środowisku cerkiewnym na początku XX wieku.

Impulsem do wszczęcia publicznej dyskusji o miejscu i roli pierwszego hierarchy w systemie władzy cerkiewnej stały się obrady ukonstytuowanej 14 stycznia 1906 roku Komisji Przedsoborowej, zajmującej się przygotowaniem projektów zmian w kościelnej strukturze organizacyjnej i opracowaniem zagadnień mających w przyszłości stanowić podstawę pracy projektowanego zgromadzenia soborowego ${ }^{2}$. Jednym z kluczowych problemów, jakie staniano przed planowanym zgromadzeniem ogólnocerkiewnym była przygotowywana przez sekcję pierwszą Komisji reforma kościelnej struktury organizacyjnej. Arcybiskup chersoński i odeski Dymitr (Kowalnickij) przedstawił na

\footnotetext{
M. Muszyński, Władza kościelna w prawosławiu rosyjskim wedtug Soboru Lokalnego 1917 - 1918 r., Warszawa 2006 [maszynopis: Uniwersytet Kardynała Stefana Wyszyńskiego], s. 143-149.
} 
forum ogólny projekt zmian w tym zakresie, zakładający odbudowę patriarchatu jako organu odpowiedzialnego za kreowanie polityki cerkiewnej, nałożenie na kierowany przez przyszłego patriarchę Świątobliwy Synod funkcji wykonawczej, administracyjnej i sądowniczej oraz oddanie władzy prawodawczej regularnie zwoływanym soborom lokalnym ${ }^{3}$.

Nieprecyzyjny, powtórzmy, model powołania patriarchatu w postaci organu wspomagającego prace Świątobliwego Synodu i soborów dookreślił profesor Ilja Bierdnikow. Rozszerzając kompetencje patriarchy o stałe przedstawicielstwo we wspomnianych organach uczony zanegował ideę wyposażenia pierwszego $\mathrm{z}$ biskupów we władzę naczelną. Tę zarezerwowano, zdaniem Bierdnikowa, jedynie dla soboru i Świątobliwego Synodu ${ }^{4}$, których rozbudowane prerogatywy automatycznie blokowały możliwość nadmiernego rozrostu, bez zgody większości, pełnomocnictw patriarchy i uzurpację władzy zwierzchniej5. Utrzymanie zasady soborowości oznaczało zatem narzucenie na osobę patriarchy licznych ograniczeń, wynikających z tradycji zarządu Kościołem wschodnim ${ }^{6}$.

W wywodach interlokutorów profesora dominowała historyczna ocena ustanowienia i funkcjonowania patriarchatu w latach 1589-1721. Okres od momentu powołania tej instytucji aż do jej zniesienia przez Piotra I scharakteryzował profesor-protojerej Kijowskiej Akademii Duchownej Fiodor (Titow). Ustanowienie patriarchatu duchowny rozpatrywał w kategoriach nieprzemyślanych reform społeczno-politycznych XVI wieku. Pochopna, w jego opinii, próba wyjścia Kościoła spod kurateli władzy państwowej w 1589 roku przyczyniła się do wzrostu autorytetu państwa moskiewskiego. Zamiast upragnionej niezależności, twierdził, Cerkiew otrzymała jedynie namiastkę swobody, gdyż będąc narzędziem realizacji imperialnej polityki carskiej została zrównana z innymi instytucjami państwowy$\mathrm{mi}^{7}$. W tym kontekście utworzenie patriarchatu na Rusi, zdaniem profesora, było początkiem samozagłady Kościoła, który kierując się w stronę tradycji katolickiej centralizacji, zatracał wielowiekowe dziedzictwo soborowości ${ }^{8}$.

Ideę dotarcia do źródeł apostolskiej tradycji interpretowano, jak w przypadku występującego na forum Komisji profesora Nikołaja Głubokowskiego, w kategoriach „obo-

\footnotetext{
Георгий (Ореханов), На пути к Собору. Церковные реформы и первая русская револючия, Москва 2002, с. 14.

4 Предсоборное Присутствие, „Прибавления к Церковным ведомостям", 1906, № 21, с. 1337.

Предсоборное Присутствие, „Прибавления к Церковным ведомостям", 1906, № 22, с. 1495. Zob. też: С. Л. Фирсов, Русская Церковь накануне перемен (конеи 1890-х - 1918 г2.), Москва 2002, с. 223; М. А. Бабкин, op. cit., с. 94-97; С. С. Бычков, Русская Церковь и императорская власть. Очерки по истории Православной Российской церкви 1900-1917 г2., Москва 1998, т. 1., с. 123; Евлогий (Георгиевский), Церковный Собор (1917-1918), [в:] Дело великого строительства иерковного. Воспоминания членов Священного Собора Православной Российской Церкви 1917-1918 годов, ред. В. Н. Воробьёв, Москва 2009, с. 550.

6 Предсоборное Присутствие..., № 21, с. 1337.

Георгий(Ореханов), Генезис русского иерковного реформаторства (1905-1906 г2.), „Богословский сборник Православного Свято-Тихоновского богословского института”, 1999, № 4, с. 297.

8 Предсоборное Присутствие..., № 22, с. 1487.
}

wiązkowego powrotu do normy" owej normy, przedstawione przez kolejnych referentów, wiodły do kolebki wschodniego chrześcijaństwa. Według profesora Iwana Sokołowa jedynie tradycyjny model zarządu wspólnotą mógł zastąpić wadliwą strukturę zarządu Cerkwią ${ }^{10}$ i przywrócić patriarsze pozycję widzialnej głowy Kościoła na ziemi, odpowiedzialnej za sprawy wewnętrzne i zewnętrzne kierowanej wspólnoty oraz separującej się od prerogatyw władzy świeckiej ${ }^{11}$. Na rzecz takiego podejścia przemawiała nasilająca się w niespokojnych czasach schyłku panowania Romanowów w Rosji potrzeba zintegrowania środowiska cerkiewnego pod egidą pierwszego hierarchy - widzialnego symbolu jedności episkopatu i wiernych. „Nie można ukrywać tego - mówił Głubokowski - że nadchodzą trudne czasy, w których przyjdzie nam, być może, nawet walczyć o prawo do istnienia. Trzeba będzie wtedy zjednoczyć się pod świętym naszym sztandarem, który powinien ktoś podnieść, trzymać i nieść przed nami" 12 .

Wyniesienie godności patriarchy ponad pozostałych biskupów, a nawet sugerowane na forum obdarzenie go atrybutami imperatorskim, spotkało się ze sprzeciwem części obradujących ${ }^{13}$. Jak podkreślał znany działacz cerkiewny profesor Nikołaj Kuzniecow Kościół nie jest budowany na autorytecie jednego człowieka. Zewnętrzne formy życia cerkiewnego, kreowane na wzór instytucji państwowych, wynaturzały jego zdaniem prawdziwe oblicze chrześcijaństwa i oddalały Cerkiew od źródeł apostolskich, od wspólnoty wiary ${ }^{14}$. Kategorycznie odrzucając model jednoosobowego zarządu Kościołem proponowano reformę systemu kolegialnego, zakładającą zmiany na poziomie działalności Świątobliwego Synodu oraz powołanie wszechrosyjskiego soboru ${ }^{15}$. Te uświęcone wielowiekową tradycją i normami kanonicznymi jednostki zarządu cerkiewnego były, w opinii apologetów soborowości, jedyną alternatywą ustroju wewnętrznego Cerkwi i rzeczywistym głosem wspólnoty prawosławnej ${ }^{16}$.

Prezentowane na forum zebrania argumenty przemawiające za patriarchatem lub sugerujące odrzucenie tej formy zarządu cerkiewnego po czterech miesiącach dyskusji przybrały postać projektu zmian wyższej administracji cerkiewnej. Określono w nim stosunek wobec władzy państwowej ${ }^{17}$, wytyczono kierunek reform Świątobliwego

Деяния Предсоборного присутстви., „Церковный вестник”, 1906, № 4, с. 97-98; Георгий (Ореханов), Реформа ВЦУ в работах Предсоборного присутствия 1906 г., [в:] Ежегодная богословская конференция Православного Свято-Тихоновского Богословского Института. Материаль, ред. В. Н. Воробьёв, Москва 1996, с. 334-336.

10 Zob. też: И. И. Соколов, О византинизме в церковно-историческом отночении. Избрание патриархов в Византии. Вселенские судьи в Византии, Санкт-Петербург 2003.

11 Предсоборное Присутствие..., № 22, с. 1517.

12 Ibidem, c. 1520.

13 Журналь и протоколь Высочайше учрежденного Предсоборного присутствия, Санкт-Петербург 1906, т. 2, с. 674.

${ }_{14}$ Предсоборное Присутствие..., № 21, с. 1408.

15 Евлогий (Георгиевский), op. cit., ń. 550; М. А. Бабкин, op. cit., c. 94 .

16 Предсоборное Присутствие..., № 21, с. 1331, 1334-1335; Предсоборное Присутствие..., № 22, с. 1531.

17 Д. В. Поспеловский, Русская православная иерковь в XX веке, Москва 1995, с. 29-30; М. А. Бабкин, ор. cit., с. 92-97; Ю. Л. Ореханов, 
Synodu i zakreślano zmiany kompetencyjne urzędu oberprokuratorskiego, bez jednoznacznego określenia kwestii restytucji patriarchatu ${ }^{18}$. Szkic powyższy, podobnie jak działalność całego zgromadzenia, miał charakter teoretyczny, a jego treść przybrała formę bprecedensu. Polegał on na wytworzeniu wokół członków Komisji Przedsoborowej iluzji władzy ustawodawczej należącej do suwerena - społeczeństwa, podczas gdy jedynie zgoda rosyjskiego cara była warunkiem niezbędnym i koniecznym dla praktycznej realizacji cerkiewnych postulatów reformatorskich. Te zaś ostatecznie odrzucił Mikołaj II 25 kwietnia 1907 roku, zamykając prace tegoż organu ${ }^{19}$.

Problem kształtu wewnętrznego Rosyjskiej Cerkwi Prawosławnej powrócił na forum ogólnocerkiewne dopiero dziesięć lat później na posiedzeniach roboczych Soboru Lokalnego Rosyjskiej Cerkwi Prawosławnejej. Uroczyste otwarcie prac zgromadzenia nastąpiło 15 sierpnia 1917 roku nabożeństwem w kremlowskim Soborze Uspienskim. Mszę odprawił honorowy członek Soboru, siedemdziesięcioletni metropolita kijowski i halicki Władimir (Bogojawlienskij). Wzięli w niej udział wszyscy delegaci soborowi w liczbie pięciuset sześćdziesięciu czterech oraz przedstawiciele władz państwowych ${ }^{21}$. Dwa dni później wybrano prezydium soborowe i rozpoczęto prace organizacyjne ${ }^{22}$. Przy opracowywaniu szczegółowego rozkładu pracy soboru kierowano się zasadami regularności spotkań i intensywności działania, co miało swoje przełożenie w uzyskanych rezultatach ${ }^{23}$. W czasie prac Soboru Lokalnego - od 15 sierpnia 1917 do 7 września 1918 roku - odbyło się w sumie sto siedemdziesiąt spotkań w trzech sesjach. Sesja pierwsza trwała od 15 sierpnia do 9 grudnia $1917 \mathrm{roku}^{24}$, druga w terminach 20 stycznia 1917 roku - 7 kwietnia 1918 roku $^{25}$, trzecia natomiast $\mathrm{w}$ dniach 19 czerwca -7 września $1918 \mathrm{roku}^{26}$.

Реформа Высшего Церковного Управления в работах Предсоборного присутствия 1906 года, [в:] Ежегодная богословская конференция Православного Свято-Тихоновского Богословского Института. Материальи, ред. В. Н. Воробьёв, Москва 1996, с. 334-336.

18 Журналь и протоколы Высочайше учрежденного Предсоборного присутствия, Санкт-Петербург 1906, т. 1, с. 45-49.

19 Георгий (Ореханов), Император Николай II и Поместный Собор Русской Православной Церкви (два письма), „Богословский сборник Православного Свято-Тихоновского богословского института", 1999, № 2, c. 69-73.

20 O Soborze zob. szerzej: K. Pawełczyk-Dura, Rosyjskie prawosławie w okresie wczesnosowieckim (1917-1927), Lublin 2014, s. 65-81.

21 Священный Собор Православной Российской Церкви. Деяния, Москва 1994, т. 1, s. 60-133.

22 С. С. Бычков, Большевики против Русской Церкви. Очерки по истории Русской Церкви (1917-1941 г2.), Москва 2006, т. 2, s. 86.

${ }_{23}$ G. Schulz, Das Landeskonzil der Orthodoxen Kirche in Rußland 1917/18 - ein unbekanntes Reformpotential, „Kirche im Osten”, $\mathrm{nr} 23$, 1995 , s. 33-40.

24 Священный Собор Православной Российской Церкви 1917-1918. Обзор деяний, первая сессия, сост. А. Г. Кравецкий, А. А. Плетнева, Г. А. Шредер, Г. Шульц, Москва 2002; Государственный архив Российской Федерации (dalej: ГАРФ), Всероссийский Церковный Поместный Собор (Священный Собор), Протоколь заседаний Собора I сессии, ф. 3431, оп. 1, д. 4, л. 1-293.

${ }_{25}$ Священный Собор Православной Российской Церкви 19171918. Обзор деяний, вторая сессия, сост. А. А. Плетнева, Г. Шульц, Москва 2001; ГАРФ, Всероссийский Церковный Поместный Собор (Священный Собор), Протоколы заседаний Собора II сессии, ф. 3431, оп. 1, д. 5, л. 1-289.

26 Свящченный Собор Православной Российской Церкви 1917-1918.
Wypracowany model organizacyjny zakładał pracę delegatów w dwudziestu dwóch sekcjach. Spory o patriarchat zdominowały posiedzenia sekcji Wyższej administracji cerkiewnej, której obradom przewodniczył biskup astrachański Mitrofan (Krasnopolskij) ${ }^{27}$. Problem restytucji patriarchatu w Rosji wybrzmiał na Soborze po raz pierwszy w wykładzie profesora Petersburskiej Akademii Duchownej Iwana Sokołowa. W wystąpieniu datowanym na 11 września przedstawił on zgromadzonym projekt zmiany personalnej przedstawiciela Świątobliwego Synodu. Miejsce świeckiego oberprokutarora zająć powinien, zdaniem mówcy, jeden z hierarchów lub pierwszy z biskupów, którego referent określił mianem patriarchy. Profesor, uzasadniając swoją pozycję, powoływał się na zapisy trzydziestego czwartego kanonu apostolskiego (,Biskupi wszelkiego narodu powinni mieć pierwszego wśród nich i uznawać go jako głowę" $)^{28}$ oraz dziewiątego kanonu soboru antiocheńskiego (,W każdej dziedzinie Biskupi powinni wybrać Biskupa nadrzędnego" $)^{29}$.

Sokołowowy projekt, dotyczący de facto przeobrażeń zachodzących na poziomie funkcjonowania władzy synodalnej, stał się przyczynkiem do szerokiej dyskusji o reformie wyższej administracji cerkiewnej i ustanowieniu w Kościele prawosławnym systemu patriarchalnego. Rozmowy prowadzone w trakcie pierwszego miesiąca posiedzeń wskazywały na rozbieżność podglądów i opinii. Spory, niekiedy zażarte, budziła pozycja patriarchy w ogólnej strukturze Kościoła prawosławnego, jego obowiązki i prawa wobec kompetencji Świątobliwego Synodu i soboru. Prelegenci, lansując swoją wizję odrodzenia Cerkwi, przywoływali argumenty historyczne, dogmatyczne i kanoniczne, wybrzmiewające już podczas posiedzeń Komisji Przedsoborowej, a każdy nowy mówca dokładał swój głos do publicznej dyskusji na temat przyszłości prawosławia w Rosji. Pogodzenie przeszłości z wymogami współczesności wymagało od obradującego duchowieństwa spojrzenia na patriarchat z pozycji kanonów, tradycji i historii, a przyjęta postawa zależała od indywidualnego zapatrywania na cele i zadania wspólnoty na początku XX wieku, które hierarchizowały proponowany model struktury Cerkwi i były wyznacznikiem kierunku poszukiwań modelu odrodzenia ${ }^{30}$.

Обзор деяний, третья сессия, сост. А. Г. Кравецкий, Г. Шульц, Москва 2000; ГАРФ, Всероссийский Церковный Поместный Собор (Священный Собор), Протоколь заседаний Собора III сессии, ф. 3431, оп. 1, д. 6, л. 1-190.

Священный Собор Православной Российской Церкви. Деяния..., т. 1, с. 43-44, 153-154; С. Л. Фирсов, op. cit., с. 535-565; М. А. Бабкин, op. cit., с. 471-472; Владислав (Цыпин), История Русской Церкви. Синодальный и новейший периоды (1700-2005), Москва 2007, с. 340; С. С. Бычков, Большевики против Русской Церкви. Очерки по истории Русской Церкви (1917-1941 г2.)..., с. 88.

28 Суt za: Каноны или Книга Правил Святых Апостолов, Святых Соборов Вселенских и Поместных и Святых Отиеев, Монреаль 1974, c. 24.

29 Cyt. za: ibidem, c. 126.

30 О преобразовании иерковного управления в России на соборном начале, „Прибавления к Церковным ведомостям”, 1905, № 45, с. $1900 ;$ И. К. Смолич, Предсоборное Присутствие 1906 года, „Журнал Московской Патриархии", 1996, № 11, с. 74-80; М. А. Бабкин, op. cit., c. 93-94; Савва (Тутунов), У истоков Предсоборного присутствия 1906 года. Церковно-общественные дискуссии и отзывы архиереев, 
Podczas posiedzenia Zebrania Ogólnego przypadającego na 11 października Mitrofan przedstawił zebranym historię patriarchatu na ziemi rosyjskiej, zwracając uwagę zebranych na najważniejsze momenty rozwoju lokalnego prawosławia - przyjęcie przez Włodzimierza Rurykowicza chrztu i następujący bezpośrednio po nim proces chrystianizacji ziem mu podległych, odbywający się pod duchową jurysdykcją jednego z patriarchatów kanonicznych - Bizancjum (Konstantynopola) ${ }^{31}$. Tradycyjny wzorzec funkcjonowania struktur Kościoła prawosławnego, twierdził hierarcha, został w pełni urzeczywistniony w Rosji dopiero w XVI wieku wraz z zajęciem tronu patriarszego przez metropolitę moskiewskiego Hioba. Zarzucenie tej wielowiekowej tradycji na rzecz ustanowienia systemu synodalnego za panowania Piotra I doprowadziło, zadaniem duchownego, do jawnego naruszenia podstaw funkcjonowania Cerkwi rosyjskiej ${ }^{32}$. Blisko dwustuletni okres ,duchowego interregnum" uświadomił, według Mitrofana, niesłuszność carskiej decyzji. Na zakończenie konstatował:

\begin{abstract}
„Potrzebujemy patriarchy jako duchowego wodza i przewodnika, który inspirowałby naród rosyjski, nawoływałby do poprawy swojego życia i podniesienia się z upadku. I sam jako pierwszy kroczyłby w tym szeregu. Nie można działać bez wodza w ogóle, także w życiu cerkiewnym. [...] Potrzebujemy patriarchy jako religijnego przewodnika rosyjskiej Cerkwi [...]. Dajcie nam ojca, dajcie orędownika i gorliwego wierzącego" ${ }^{\text {"33. }}$.
\end{abstract}

Reforma wyższej administracji cerkiewnej prowadzona w kierunku restytucji patriarchatu oznaczała, jak wynika z analizy przemówień soborowych, odrzucenie kanoniczności systemu piotrowego oraz przekreślenie dwustu lat funkcjonowania Cerkwi w Imperium Romanowów i sprowadzenie Kościoła prawosławnego do roli instytucji pozbawionej dziedzictwa przeszłości. Takie rozumowanie było dla profesora Sergiusza Bułgakowa równoznaczne z przejściem od tradycji Kościoła wschodniego do protestanckiej eklezjologii cuius regio, eius religio ${ }^{34}$, zaś dla protojereja Nikołaja (Dobronrawowa) oznaczało rozbicie jedności religijnej Imperium, następujące w wyniku rywalizacji biskupów każdej z nacji wchodzących w skład cesarstwa i prowadzące w konsekwencji do niebezpieczeństwa wykształcenia się odrębnych patriarchatów Ukrainy, Syberii i pozostałych ${ }^{35}$.

\footnotetext{
„Московские Епархиальные Ведомости”, 2011, № 7/8, с. 141-144.

31 Иакинф (Дестивель), Поместный Собор Российской Православной Церкви 1917-1918 г2. и принцип соборности, Москва 2008, с. 128. 32 Владислав (Цыпин), op. cit., с. 341.

33 Суt. za: Священный Собор Православной Российской Церкви. Деяния, Москва 1994, т. 2, с. 229, 235.

34 ГАРФ, Всероссийский Церковный Поместный Собор (Священный Собор), Протокол и стенограмма заседания Собора от 28 октября 1917 года посвященного рассмотрению вопроса о восстановлении патриариества в России и кодификации канонического права. Материаль к протоколу, ф. 3431, оп. 1, д. 32, л. 62-69.

35 Ta samą teze głosił P. Р. Kudriajew: ГАРФ, Всероссийский Церковный Поместный Собор (Священный Собор), Протокол заседания Собора от 11 октября 1917 года посвященного обсуждению вопроса о восстановлении патриармества в России, об информации населе-
}

Odniesienie do przeszłości, w kontekście sporów o patriarchat, dotykało subiektywnych opinii poszczególnych prelegentów. Poglądy te nakładały się w znacznej mierze na sposób rozumienia i interpretacji historii istnienia patriarchatu w państwie rosyjskim i zasad funkcjonowania kanonicznych struktur nadrzędnych w pozostałych prawosławnych kościołach autokefalicznych. Oderwanie współczesności od przeszłości było, zdaniem stronników ustroju hierarchicznego, zaprzeczeniem tradycji. Bo czy od setek lat nie trwały nadal, pomimo burz i zawirowań dziejowych, poszczególne patriarchaty Wschodu? Jako przykład Kościoła utrzymującego strukturę jedynowładztwa religijnego najczęściej wskazywano na kamień węgielny prawosławia, a mianowicie na Bizancjum (Konstantynopol). Profesor Petersburskiej Akademii Duchownej Iwan Sokołow podliczył nawet, iż od 1453 roku aż do końca XIX wieku na obszarze tej kościelnej jednostki administracyjnej, zarządzanej oficjalnie przez patriarchę, zachowano zasadę soborowości. W ciągu czterech stuleci zwołano prawie pięćdziesiąt soborów, działał także synod jako organ soborowy ${ }^{36}$. Zresztą, co wyartykułował Andriej Kuliaszew, w Cerkwi rosyjskiej właśnie okres istnienia ustroju patriarchalnego należał do najbardziej bujnych w zgromadzenia soborowe na przestrzeni całej historii ${ }^{37}$.

Nikołaj Kuzniecow wskazywał na brak ścisłego określenia przez średniowieczne kanony pozycji pierwszego hierarchy i późniejsze wykształcenie, pod wpływem katolicyzmu, zasady nadrzędności pierwszego biskupa ${ }^{38}$. Jak dobitnie podkreślał protojerej Nikołaj (Cwietkow) patriarchat w ogóle nie istniał, gdyż wschodni Kościół apostolski nie znał określenia primus inter pares. Niezgodne z nauczaniem Pisma Świętego i tradycją apostolską wywyższenie jednego nad pozostałych nie mogło stanowić podstawowej zasady budowy życia cerkiewnego i było rezultatem dążenia do centralizacji władzy kościelnej na Zachodzie $^{39}$. Odwołując się do historii papieskiego Rzy-

ния о работе Собора, о возвращении иерковных типографии реквизированных местными советами. Материаль к протоколу, ф. 3431, оп. 1 , д. 25 , л. 47 об-50 об.

36 ГАРФ, Всероссийский Церковный Поместный Собор (Священный Собор), Протокол заседания Собора от 23 октября 1917 года посвяменного обсуждению вопроса о восстановлении патриаршества, об организации митрополичьей кафедры в Бессарабии, о передаче иерковно-приходских икол в ведение Министерства просвещения. Материаль к протоколу, ф. 3431, оп. 1, д. 30, л. 23-25, 62-74, 90-92 об, 122-134.

37 ГАРФ, Всероссийский Церковный Поместный Собор (Свящзенный Собор), Протокол заседания Собора от 21 октября 1917 года посвященного обсуждению вопроса о восстановлении патриаршества в России, об автокефалии (автономии) грузинской иеркви, об изменениях в личном составе Собора. Материалы к протоколу, ф. 3431, оп. 1, д. 29, л. 52 об - 53 об, 100-101.

38 ГАРФ, Всероссийский Церковный Поместный Собор (Священный Собор), Протокол заседания Собора от 14 октября 1917 года посвященного обсуждению вопроса о восстановлении патриаршества в России, о плане работы Собора, о переговорах с Временнымм правительством об оставлении приходских школ. Материалы к протоколу, ф. 3431, оп. 1, д. 26, л. 50-51, 53-55.

39 ГАРФ, Всероссийский Церковный Поместный Собор (Священный Собор), Протокол и стенограмма заседания Собора от 19 октября 1917 года посвяменного рассмотрению вопроса о восстановлении патриаршества и о передаче иерковно-приходских икол в ведение Министерства просвещения. Материаль к протоколу, ф. 3431, оп. 1, д. 28, л. 23-25. 
mu, podkreślano niebezpieczeństwo złożenia losów całej wspólnoty w ręku zwykłego człowieka. Od jego charakteru, postawy i osobistych decyzji zależeć miała przyszłość prawosławia rosyjskiego. A przecież kolegialność, bezpieczniejsza alternatywa patriarchatu, stwarzała możliwości wyboru opcji optymalnej ${ }^{40}$. Pokładanie losów całej wspólnoty na barkach patriarchy duchowny Leonid (Iwanicki) skomentował słowami: „Patriarcha nie jest czarodziejską różdżką, która jest w stanie wszystko zmienić" ${ }^{\prime 4}$. W tym poglądzie wtórował mu profesor Ilja Gromogłasow mówiąc, że „Sama z siebie godność patriarchy nie czyni ludzi ni mądrymi, ni świętymi, ni utalentowanymi administratorami" ${ }^{42}$.

Apologetą tradycji patriarchatu w Cerkwi prawosławnej stał się wykładowca Moskiewskiej Akademii Duchownej Iłarion (Troickij). Archimandryta podkreślał, iż począwszy od II wieku naszej ery w Kościele powszechnym przyjęto apostolską normę jednoosobowego zarządu na obszarze terytorium administracyjnego dawnego Cesarstwa Rzymskiego $0^{43}$. Mniej więcej w tym okresie, jak twierdził duchowny, można dostrzec zjawisko jednoczenia się wiernych wokół największych miast danej prowincji Imperium, a więc wokół metropolii. Fakt ów zatwierdziły decyzje pierwszych soborów powszechnych, z czasem zyskujące status kanonów, w tym trzydziesty czwarty kanon apostolski, dziewiąty kanon Soboru antiocheńskiego i kanon szósty Soboru nicejskiego. W tworzącym się systemie określonym przez mówcę jako „bizantyński” patriarcha był „swego rodzaju spadkobiercą [...] imperatorów”"4, a więc duchownym pomocnikiem, egzarchą i spowiednikiem prawosławnego władcy kraju. Ideał powyższy w najczystszej formie urzeczywistnił się w Rosji, zdaniem Iłariona, w czasach patriarchy Nikona i cara Aleksego Michajłowicza. Ścisła współpraca duchowego przywódcy oraz świeckiego panującego, tworzących wspólnymi siłami potęgę imperium rosyjskiego, doprowadziła do stabilnego rozwoju wewnętrznego kraju oraz przyczyniła się do wzrostu autorytetu tronu patriarszego. Zaburzenie owej naturalnej koegzystencji stanowiła dla prelegenta epoka synodalna. Jedynie zwołanie soboru lokalnego, jak uważał, stwarzało dogodne warunki restytucji struktur kanoniczych w zarządzie cerkiewnym, dawało możliwość otwarcia nowej epoki w życiu wspólnoty, w której uzyskałaby ona dawną swobodę i niezależnośćc ${ }^{45}$. Na forum soborowym Iłarion podkreślał:

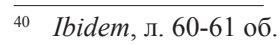

41 ГАРФ, Всероссийский Церковный Поместный Собор (Свяменный Собор), Протокол и стенограмма заседания Собора от 25 октября 1917 года посвященного рассмотрению вопроса о восстановлении патриариества в России. Материаль к протоколу, ф. 3431, оп. 1, д. 31 , л. 90 .

42 Ibidem, л. 92.

43 Священномученик Иларион (Трочикий). Творения в трёх томах, Москва 2004, т. 3, с. 547.

44 Ibidem, c. 104.

45 Cyt. za: Иларион (Троицкий), Исторический очерк сущзествования Православной Церкви в России за время с 1613 г. по настоящий момент, „Вестник Православного Свято-Тихоновского Гуманитарного Университета. Серия: История. История Русской Православной Церкви”, 2010, № 2, с. 93-121.
}

„Już wiele słów wysłuchaliśmy na temat patriarchatu. Większość mówiących tutaj o patriarchacie - i za, i przeciw - rozpatrywała ten problem od strony racjonalizmu i chwili obecnej. Jedni nakładali na patriarchat - być może nawet przesadzając - nadzieje charakteru religijnego, a nawet i politycznego; inni starali się wyrazić swoje rozczarowanie tymi, którzy owe nadzieje rozbudzali. Przy tym jednak w mowach tej i drugiej strony przebrzmiewała jedna i ta sama nuta: można wrócić do instytucji patriarchatu, a można - z punktu widzenia pożytku praktycznego i wymogów chwili - nie wracać. Dla mnie pytanie o powrót do patriarchatu postawione jest zupełnie inaczej. My nie możemy nie wrócić do patriarchatu; my jesteśmy zobowiąani do jego jak najszybszego przywrócenia, ponieważ patriarchat jest podstawą struktury każdej Cerkwi lokalnej”46.

Namiastka kanonicznej i historycznej władzy zwierzchniej w postaci kadłubowego Świątobliwego Synodu nie spełniła, co podkreślali zwolennicy opcji propatriarszej, pokładanych w nim nadziei. Kolegialność dzieliła zarówno siłę i energię poszczególnej jednostki, jak też odpowiedzialność za popełnione błędy ${ }^{47}$. Patrząc na te argumenty przez pryzmat 1917 roku, a więc wybuchu przewrotu bolszewickiego, wojny domowej, upadku monarchii i powołania nowego rządu dążenie do centralizacji w obliczu zagrożenia należy rozpatrywać $\mathrm{w}$ ramach instynktu samozachowawczego. Utrzymanie minimalnej niezależności przez ginącą $\mathrm{w}$ terrorze wspólnotę wymagało aktywnego włączenia się do gry wybitnej osobowości - charyzmatycznego patriarchy, którego książę Jewgienij Trubieckoj określał mianem, „żywego przedstawiciela życia narodowego, żywego nosiciela władzy, żywego przykładu"48.

Konieczność restytucji tradycji powoływania pierwszego hierarchy wynikała ponadto, jak podkreślał protojerej Leonid (Turkiewicz), z procesów centralizacji poszczególnych części Cerkwi rosyjskiej, w tym także prawosławnej diaspory zagranicznej. Duchowny odwoływał się do siły funkcjonującego od setek lat pod egidą papieża katolicyzmu i słabości prawosławia rosyjskiego, pozbawionego przez Piotra I władzy zwierzchniej w postaci jednoosobowego kierownictwa ${ }^{49}$. „Powrót do instytucji patriarchatu jest powrotem do wiary narodowej w jej pełni i pięknie" - wołano z ław soborowych ${ }^{50}$. Kompleksy niż-

\footnotetext{
46 Idem, Почему необходимо восстановить Патриаршество?, „Богословский вестник”, 1917, № 10/12, с. 418.

47 ГАРФ, Всероссийский Церковный Поместный Собор (Священный Собор), Протокол заседания Собора от 11 октября 1917 года посвященного обсуждению вопроса о восстановлении патриариества в России, об информации населения о работе Собора, о возвращении церковных типографии реквизированных местными советами. Материальь к протоколу..., л. 37-47.

48 ГАРФ, Всероссийский Церковный Поместный Собор (Священный Собор), Протокол и стенограмма заседания Собора от 19 октября 1917 года посвященного рассмотрению вопроса о восстановлении патриаршества и о передаче иерковно-приходских икол в ведение Министерства просвещения. Материальл к протоколу..., л. 28-30, 57-60 об, 53-57 об, 93-94 об, 135-140.

49 Ibidem, л. 65 об-68.

50 ГАРФ, Всероссийский Церковный Поместный Собор (Священный
} 
szości wobec pozostałych Kościołów miało uleczyć właśnie obsadzenie rosyjskiego tronu patriarszego. Na forum soborowym o tej potrzebie mówili głośno protojerej Jemielian (Biekariewicz), duchowny Władimir (Wostokow) i wykładowca Władimir Niedielskij oraz wspomniany wyżej profesor Sergiusz Bułgakow ${ }^{51}$.

Silne, scentralizowane jedynowładztwo, popierane przez aparat biurokratyczny, stanowiło według profesora Borysa Titlinowa rzeczywiste zagrożenie dla losów rosyjskiego prawosławia ${ }^{52}$. Zdaniem prelegenta, patriarchat był kontynuacją monarchicznego absolutyzmu, który w wymiarze politycznym Rosja w 1917 roku całkowicie odrzuciła. Wybuch przewrotu bolszewickiego, wojna domowa i upadek dynastii Romanowów, w jego opinii, winny skutkować odejściem od skostniałej instytucji patriarchatu i przyjęciem w Kościele prawosławnym liberalnego modelu demokratycznego ${ }^{53}$ :

„Moskiewski Sobór, jak już wspomniano, zajął się zagadnieniem powołania «monarchy cerkiewnego» w chwili, kiedy wydarzenia polityczne rozwijały się w kierunki rewolucyjnego apogeum. 25 października [7 listopada nowego stylu - KPD] 1917 roku upadł Rząd Tymczasowy [Aleksandra - KPD] Kiereńskiego. Władza przeszła w ręce Rad, to znaczy objęło ją lewe skrzydło ruchu socjalistycznego, którego punkt widzenia na sprawy religijne miał charakter radykalny. Wydawałoby się, że przewrót polityczny powinien wymusić na Soborze postawę asekuracyjną wobec tak ważnego problemu, jakim było powołanie instytucji patriarchatu, mającego dla rewolucji korzenie monarchiczne. Ale widzimy coś zupełnie innego. Pierwszą odpowiedzią Soboru na przewrót

Собор), Протокол и стенограмма заседания Собора от 25 октября 1917 года посвященного рассмотрению вопроса о восстановлении патриариества в России. Материаль к протоколу..., л. 43 об.

51 ГАРФ, Всероссийский Церковный Поместный Собор (Священный Собор), Протокол и стенограмма заседания Собора от 19 октября 1917 года посвященного рассмотрению вопроса о восстановлении патриаршества и о передаче иерковно-приходских икол в ведение Министерства просвещения. Материальк к протоколу..., л. 25 об -28, 31 об -33, 52-56 об, 61-62 об; ГАРФ, Всероссийский Церковный Поместный Собор (Священный Собор), Протокол заседания Собора от 21 октября 1917 года посвященного обсуждению вопроса о восстановлении патриаршества в России, об автокефалии (автономии) грузинской церкви, об изменениях в личном составе Собора. Материалы к протоколу..., л. 51-52 об, 98-99 об.

52 ГАРФ, Всероссийский Церковный Поместный Собор (Священный Собор), Протокол заседания Собора от 14 октября 1917 года посвяменного обсуждению вопроса о восстановлении патриаршества в России, о плане работь Собора, о переговорах с Временныл правительством об оставлении приходских икол. Материаль к протоколу..., Л. 58 об - 59 об.

53 ГАРФ, Всероссийский Церковный Поместный Собор (Священный Собор), Протокол заседания Собора от 21 октября 1917 года посвященного обсуждению вопроса о восстановлении патриариества в России, об автокефалии (автономии) грузинской иеркви, об изменениях в личном составе Собора. Материаль к протоколу..., л. 65-68 об, 80-82. październikowy były właśnie przyspieszone prace nad ustanowieniem jedynowładztwa kościelnego" ${ }^{44}$.

Przedstawione na Soborze argumenty pro et contra ustanowienia jedynowładztwa kościelnego można określić ogólnie mianem dwóch wizji odrodzenia Cerkwi po okresie synodalnym. Jedna z nich zakładała powrót do tradycyjnej dla Kościołów Wschodu instytucji patriarchatu, a więc tym samym oznaczała odrzucenie dziedzictwa epoki piotrowej i rozpoczęcie nowego etapu życia religijnego po 1917 roku. Konserwatyzm poglądów zwolenników tej opcji zamykał się przede wszystkim w granicach kanoniczności i historyczności funkcjonowania Cerkwi pod wodzą pierwszego wśród biskupów. Błąd w decyzji Piotra I polegał, ich zdaniem, na odwróceniu się od norm bizantyńskich i przejściu na drogę obcej prawosławiu liberalizacji stosunków wewnątrzcerkiewnych. Świątobliwy Synod, namiastka władzy zwierzchniej, nie wypełnił swojego zadania. Rosyjskiej Cerkwi u progu nowej epoki potrzebny był przywódca - symbol jedności i siły.

Druga wizja odrodzenia, lansowana była przez stronnictwa liberalne, deprecjonowała znaczenie patriarchatu na przestrzeni dziejów. Członkowie tej grupy byli w większości ludźmi negatywnie nastawionymi od prób usamodzielnienia się Kościoła prawosławnego. Opcja zależności od władzy państwowej (jakąkolwiek by ona nie była - czy to imperator czy samozwańczy wódz narodu) stanowiła dla nich najbezpieczniejszy wariant współżycia między państwem a Kościołem. Odejście od urządzeń instytucjonalnych epoki synodalnej, a więc tym samym reorganizacja naczelnych organów cerkiewnych, oznaczało usamodzielnienie się instytucji religijnej kosztem utraty opieki świeckiej.

Debata nad reformą systemu synodalnego została zakończona 28 października 1917 roku. Końcowy rezultat prac prawno-legislacyjnych Soboru Lokalnego ogłaszał wspólnocie restytucję patriarchatu w Rosji ${ }^{55}$. Zamknęła ona ostatecznie trwającą ponad dwieście lat w dziejach Rosyjskiej Cerkwi Prawosławnej epokę synodalną i ucięła kilkunastoletnie (a nawet kilkuwiekowe, biorąc pod uwagę kontrowersje narosłe przez kolejne epoki wokół decyzji Piotrowej) spory na temat drogi, którą powinna kroczyć przez następne dziesięciolecia. Tron patriarszy stał się widocznym symbolem siły prawosławia rosyjskiego, odradzającego się w nowych warunkach politycznych i społecznych epoki sowieckiej.

Б. В. Титлинов, Церков во время револючии, [в:] Дело великого строительства иерковного. Воспоминания членов Священного Собора Православной Российской Церкви 1917-1918 годов, ред. В. Н. Воробьёв, Москва 2009, с. 338.

55 Cyt. za: М. А. Бабкин, op. cit., c. 480. Szerzej na temat każdej z wymienionych władz w Cerkwi zob.: Иакинф (Дестивель), op. cit., c. $123-124$. 


\section{Bibliografia}

\section{Archiwa}

\section{Государственный архив Российской Федерации}

Всероссийский Церковный Поместный Собор (Священный Собор) ф. 3431 , оп. 1 , д. $4 ; 5 ; 6 ; 25 ; 26 ; 28 ; 29 ; 30 ; 31$; 32.

Протоколы заседаний Собора I сессии, д. 4.

Протоколы заседаний Собора II сессии, д. 5.

Протоколы заседаний Собора III сессии, д. 6 .

Протокол и стенограмма заседания Собора от 28 октября 1917 года посвященного рассмотрению вопроса о восстановлении патриаршества в России и кодификации канонического права. Материалы к протоколу, д. 32.

Протокол заседания Собора от 11 октября 1917 года посвященного обсуждению вопроса о восстановлении патриаршества в России, об информации населения о работе Собора, о возвращении церковных типографии реквизированных местными советами. Материалы к протоколу, д. 25.

Протокол заседания Собора от 23 октября 1917 года посвященного обсуждению вопроса о восстановлении патриаршества, об организации митрополичьей кафедры в Бессарабии, о передаче церковно-приходских школ в ведение Министерства просвещения. Материалы к протоколу, д. 30.

Протокол заседания Собора от 21 октября 1917 года посвященного обсуждению вопроса о восстановлении патриаршества в России, об автокефалии (автономии) грузинской церкви, об изменениях в личном составе Собора. Материалы к протоколу, д. 29.

Протокол заседания Собора от 14 октября 1917 года посвященного обсуждению вопроса о восстановлении патриаршества в России, о плане работы Собора, о переговорах с Временным правительством об оставлении приходских школ. Материалы к протоколу, д. 26.

Протокол и стенограмма заседания Собора от 19 октября 1917 года посвященного рассмотрению вопроса о восстановлении патриаршества и о передаче церковно-приходских школ в ведение Министерства просвещения. Материалы к протоколу, д. 28.

Протокол и стенограмма заседания Собора от 25 октября 1917 года посвященного рассмотрению вопроса о восстановлении патриаршества в России. Материалы к протоколу, д. 31.

\section{Czasopisma}

„Kirche im Osten”: 1995 (nr 23).

„Богословский вестник”: 1917 (№ 10/12).

„Богословский сборник Православного Свято-Тихоновского богословского института": 1999 (№ 2; 4).

„Вестник Православного Свято-Тихоновского Гуманитарного Университета. Серия: История. История Русской Православной Церкви”: 2010 (№ 2).
„Журнал Московской Патриархии”: 1996 (№ 11).

„Московские Епархиальные Ведомости”: 2011 (№ 7/8).

„Прибавления к Церковным ведомостям”: 1905 (№ 45); 1906 (№ 21; 22).

„Церковный вестник”: 1906 (№ 4).

\section{Opracowania}

Muszyński M., Władza kościelna $w$ prawosławiu rosyjskim wedtug Soboru Lokalnego 1917-1918 r., Warszawa 2006 [maszynopis: Uniwersytet Kardynała Stefana Wyszyńskiego].

Pawełczyk-Dura K., Rosyjskie prawostawie $w$ okresie wczesnosowieckim (1917-1927), Lublin 2014.

Бабкин М. А., Священство и Царство. Россия начало ХХ века - 1918 г. Исследования и материалы, Москва 2011.

Бычков С. С., Большевики против Русской Церкви. Очерки по истории Русской Церкви (1917-1941 ге.), Москва 2006, т. 2.

Русская Церковь и императорская власть. Очерки по истории Православной Российской церкви 1900-1917 г2., Москва 1998, т. 1.

Владислав (Цыпин), История Русской Церкви. Синодальный и новейший периоды (1700-2005), Москва 2007, с. 340.

Георгий (Ореханов), На пути к Собору. Церковные реформы и первая русская революичи, Москва 2002.

Дело великого строительства иерковного. Воспоминания членов Священного Собора Православной Российской Церкви 1917-1918 годов, ред. В. Н. Воробьёв, Москва 2009.

Ежегодная богословская конференция Православного Свято-Тихоновского Богословского Института. Материальь, ред. В. Н. Воробьёв, Москва 1996.

Журналь и протоколь Высочайше учрежденного Предсоборного присутствия, Санкт-Петербург 1906, т. 1 і 2.

Иакинф (Дестивель), Поместный Собор Российской Православной Церкви 1917-1918 г2. и приничи соборности, Москва 2008.

Каноны или Книга Правил Святых Апостолов, Святых Соборов Вселенских и Поместных и Святых Отиев, Монреаль 1974.

Поспеловский Д. В., Русская православная церковь в ХХ веке, Москва 1995.

Священномученик Иларион (Троиикий). Творения в трёх томах, Москва 2004, т. 3 .

Священный Собор Православной Российской Церкви 1917-1918. Обзор деяний, третья сессия, сост. А. Г. Кравецкий, Г. Шульц, Москва 2000.

Священный Собор Православной Российской Церкви 1917-1918. Обзор деяний, вторая сессия, сост. А. А. Плетнева, Г. Шульц, Москва 2001.

Свяменный Собор Православной Российской Церкви 1917-1918. Обзор деяний, первая сессия, сост. А. Г. Кравецкий, А. А. Плетнева, Г. А. Шредер, Г. Шульц, Москва 2002. 
Священный Собор Православной Российской Церкви. Деяния, Москва 1994, т. 1 і 2.

Соколов И. И., О византинизме в иерковно-историческом отнотении. Избрание патриархов в Византии. Вселенские судьи в Византии, Санкт-Петербург 2003

Фирсов С. Л., Русская Церковь накануне перемен (конеи 1890-x - 1918 гг), Москва 2002

Rozmiar artykułu: 1,1 arkusza wydawniczego 
ISSN 1508-7719

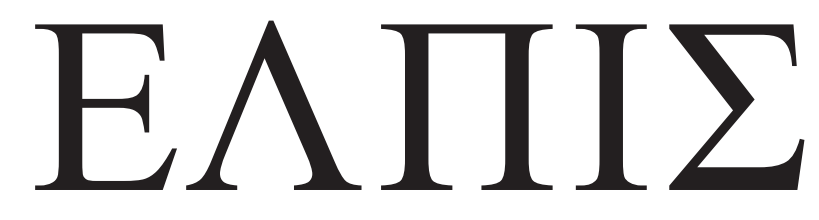

CZASOPISMO TEOLOGICZNE KATEDRY TEOLOGII PRAWOSŁAWNEJ UNIWERSYTETU W BIAŁYMSTOKU

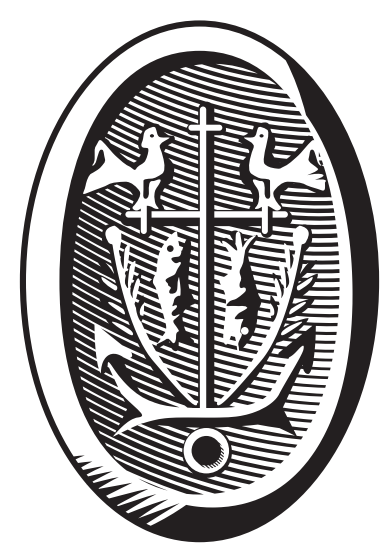

ADRES REDAKCJI

15-097 Białystok, ul. M. Skłodowskiej-Curie 14 tel. 85 745-77-80, e-mail: redakcja@elpis.edu.pl www.elpis.uwb.edu.pl 